\title{
Black Cumin Seed Oil Antidiabetogenic by Increasing Pancreatic p53 Expression
}

\author{
Akrom $^{1}$, Rizma Nurfadjrin ${ }^{2}$, Endang Darmawan ${ }^{3}$, Titiek Hidayati ${ }^{4}$ \\ ${ }^{1,2,3}$ Pharmacy Faculty, Universitas Ahmad Dahlan, Yogyakarta, Indonesia \\ ${ }^{1}$ Ahmad Dahlan Drug Informatian and crisis Center (ADDICC), Indonesia \\ ${ }^{4}$ Family Medicine and Public Health Department, Medicine and Health Science Faculty, \\ Universitas Muhammadiyah Yogyakarta, Indonesia
}

\begin{tabular}{l} 
Article Info \\
\hline Article history: \\
Received Jun 9, 2018 \\
Revised Sep 8, 2018 \\
Accepted Sep 15, 2018
\end{tabular}

\section{Keyword:}

Alloxan

Antidiabetogenic

Black seed cumin oil

Malondialdehyde

Pancreatic P53 expression

\begin{abstract}
Black cumin seed oil (BCSO) contains many thymoquinone and unsaturated fatty acids that act as antioxidants. Thymoquinone was thought to inhibit pancreatic damage and prevent hyperglycemia by involving p53. The study aimed to determine the BCSO effect on Malondialdehyde (MDA) levels and p53 expression of pancreatic tissues in alloxan-induced Sprague Dawley (SD) rats. This study used Pre and Post Test with Control Group Design with 49 male Sprague Dawley rats aged 30 days weighing 150 - 300 gram. Rats were divided into 7 groups: Group I, the normal control group receiving standard feeding and drinking; Group II, the negative control group receiving alloxan; Group III \& IV, the treatment groups, receiving BCSO with a dose of $6.9 \mathrm{mg} / \mathrm{KgBW}$ (BCSO6.8) and $68 \mathrm{mg} / \mathrm{KgBW}$ (BCSO68 group); Group V, the positive control 1 group receiving simvastatin $10 \mathrm{mg} / \mathrm{KgBW}$; Group VI, the positive control 2 group receiving vitamin C $18 \mathrm{mg} / 200 \mathrm{mgBW}$; Group VII, the solvent control receiving DMSO. The treatment groups received two different doses per day for 9 days orally. Blood MDA and glucose levels were determined by spectrophotometry and p53 expression of pancreas tissues were read by a pathologist. The results show that the BCSO68 group had a decreased activity of MDA and glucose but a higher expression of p53 in pancreatic tissues compared to the BCSO6.8 group. Decreased Malondialdehyde levels in the BCSO68 group were similar to those in the vitamin $\mathrm{C}$ group but lower than those in the simvastatin group $(\mathrm{p}<0.05)$. It can be concluded that the BCSO administration of $68 \mathrm{mg} / \mathrm{KgBW}$ per day can decrease blood Malondialdehyde and glucose levels and increase p53 expression.
\end{abstract}

Copyright $(9) 2018$ Institute of Advanced Engineering and Science. All rights reserved.

\section{Corresponding Author:}

Akrom,

Department of Pharmacology and Clinical Pharmacy,

Pharmacy Faculty, Universitas Ahmad Dahlan,

Jl. Prof. Dr. Soepomo SH, Janturan, Yogyakarta 55164, Indonesia.

Email: akrom@pharm.uad.ac.id

\section{INTRODUCTION}

Diabetes mellitus (DM) is one of the public health problems in Indonesia. The government has implemented DM disease management guideline but the DM mortality rate and new incidence continue to increase. Diabetes with hyperglycemic conditions can cause various complications such as diabetic nephropathy, stroke, ischemic heart, retinopathy, or neuropathy [1]. Hyperglycemia often occurs in DM [2]. Hyperglycemia produces excessive free radicals resulting in oxidative stress [3]. Free radicals cause cell damage through lipid membrane peroxidation [4]. Increased free radicals will often be followed by increased levels of Malondialdehyde (MDA) and inflammation. Clinically, MDA with inflammatory mediators is a biomarker of oxidative stress in the body [5]. Increased MDA levels have been shown to be associated with 
post-stroke event [6], incidence of Post-Traumatic Stress Disorder [7], and the incidence of preeclampsia, where the condition is closely related to oxidative stress characterized by high reactive oxygen superfamily (ROS) and inflammatory reaction [8].

Alloxan is a diabetogenic compound that destroys pancreatic islet cells so that insulin production is reduced and hyperglycemia occurs [9]. Intraperitoneal alloxan induction has been shown to cause damage to pancreatic islet cells and the incidence of hyperglycemia preceded by elevated levels of ROS and MDA and followed by an inflammatory reaction $[10,11]$. ROS and NOS due to exposure to alloxan spur lipid membrane peroxidation and oxidation reactions in proteins and DNA [4, 11, 12]. Pancreatic islet cell destruction due to exposure to alloxan is characterized by genetic damage (DNA) and elevated MDA levels [13-15].

P53 gene plays an important role in modulating the effect of elevated intracellular ROS or NOS levels, repairing genetic damage and regulating the balance of inflammatory responses [12, 16, 17]. P53 protein plays a role in stimulating apoptosis in cells undergoing genetic stress due to oxidative stress and inhibiting the inflammatory reaction through suppression of pro-inflammatory transcription factor NFkappaB. Under normal conditions, the p53 gene is inactive. P53 gene is activated by the presence of oxidative stress or genetic damage. $[18,19]$.

Several studies have proven that Black cumin (Nigella sativa L.) can lower blood glucose levels [20]. Thymoquinone is identified as a major component (over 50\%) of black cumin seed essential oil, or BCSO [21]. Thymoquinone proved to have an effect as an antioxidant and immunomodulator [22-24]. It performs its activity as an antioxidant by means of a hydrogen donor to free radicals [23]. High levels of timoxygen in BCSO are expected to act as antioxidants and can prevent cell damage induced by alloxan. Based on previous studies, it is evident that BCSO may increase p53 expression in the liver tissue of alloxaninduced rats [25]. We hypothesize that thymoquinone can prevent pancreatic cell damage, prevent hyperglycemia, and increase p53 expression. This study aims to determine the effect of BCSO on Malondialdehyde levels in alloxan-induced Sprague dawley rats.

\section{RESEARCH METHOD}

\subsection{Tools and Materials}

This research is an experimental research with Pretest and Posttest Control Design. This study uses spectrophotometer (UV-1201V Shimadzu), analytical balance (Adventurer) for weighing samples, spuit injection (Terumo), oral mouse sonde, capillary pipe, measuring cup (pyrex), mortar stamper, Eppendorf, mouse cage (pyrex), funnel (pyrex), flacon, beaker (pyrex), and test tube (pyrex). The ingredients used are black cumin seeds (PT Mega Agung Setia), vitamin C from IPI tablets, simvastatin $10 \mathrm{mg}$ generic tablets (SOHO), DMSO (dimethyl sulfoxide), alloxan monohydrate (Sigma), aquadest, heparin (anticoagulant), TBA reagents, p53 monoclonal antibodies, secondary antibody and immunohistochemical tissue dyes i.e. DAB. The experimental animals used are 49 Sprague Dawley male rats aged 30 days weighing from 150 to 300 grams obtained from the National Food and Drug Test Center of Animal Laboratory of Experiments, BPOM RI Jakarta. The animals are divided into 7 groups.. The study protocol was reviewed and received a letter of ethical clearance from the research ethics committee of LPPT UGM no 222/KEC-LPPT/III/2015.

\subsection{Research procedure}

\subsubsection{Treatment and Induction of Alloxan}

A total of 49 SD rats aged 3 weeks were randomly divided into seven groups and quarantined for 7 days prior to the treatment. The 7 groups were: Group I, the normal control group receiving standard feeding and drinking; Group II, the negative control group receiving alloxan; Group III \& IV, the treatment groups, receiving $\mathrm{BCSO}$ with a dose of $6.9 \mathrm{mg} / \mathrm{KgBW}$ (BCSO6.8) and $68 \mathrm{mg} / \mathrm{KgBW}$ (BCSO68 group); Group V, the positive control 1 group receiving simvastatin $10 \mathrm{mg} / \mathrm{KgBW}$; Group VI, the positive control 2 group receiving vitamin C $18 \mathrm{mg} / 200 \mathrm{mgBW}$; Group VII, the solvent control receiving DMSO. After the adaptation period, groups II-VII began to receive treatment performed orally every day before meals for 7 days. On day 7 , the mice were induced with alloxan $(125 \mathrm{mg} / \mathrm{kgBW})$ intraperitoneally. On day 8 , their blood glucose levels were tested. On day 9, their blood MDA levels were examined.

\subsubsection{Checking Blood Glucose and MDA Levels \\ a. Examination of Blood Sugar Levels}

On the 7th (before alloxan induction), 8th and 9th day, the test animals were taken blood samples for the examination of glucose levels. Blood samples taken from mice's orbital sinus were collected into Eppendorf containing anticoagulant (heparin) and left at room temperature for at least 30 minutes, followed by low-speed centrifugation $(4000 \mathrm{rpm})$ for 15 minutes. Blood will be separated into two parts: red at the 
bottom and light yellow plasma at the top. After centrifugation, plasma samples were separated by using a Pasteur pipette and then the glucose levels were examined using spectrophotometric method.

\section{b. Examination of MDA Levels}

On the 9th day, blood was taken for MDA examination. Blood samples taken from mice's orbital sinus were collected into Eppendorf containing anticoagulant (heparin) and left at room temperature for at least 30 minutes, followed by low-speed centrifugation $(4000 \mathrm{rpm})$ for 15 minutes. Blood will be separated into two parts: red at the bottom and light yellow plasma at the top. After centrifugation, plasma samples were separated by using a Pasteur pipette and then the MDA levels were examined The level was measured using $0.05 \mathrm{ml}$ of sample added with $0.25 \mathrm{ml} \mathrm{TBA} 40 \mathrm{Mm}, 0.75 \mathrm{ml}$ of H3PO4 1\%, and $0.45 \mathrm{ml}$ of $\mathrm{H} 2 \mathrm{O}$. The sample and reagents were mixed evenly with the divortex, and the resulting mixture was heated in a water bath for 60 minutes at $100^{\circ} \mathrm{C}$. Next, the sample was removed from the water bath and put into an ice bath to cool until the temperature reached $30 \mathrm{oC}$. The cold sample was applied to column C18. Before the absorbance was read, the $\mathrm{C} 18$ column was elucidated with $5 \mathrm{ml}$ methanol and then discarded, eluted with $5 \mathrm{ml}$ of $\mathrm{H} 2 \mathrm{O}$ then discarded, and finally parsed into column C18 and then discarded. The MDA components would be bound to column C18. To remove non-MDA components, the column was eluted again with $4 \mathrm{ml}$ of $\mathrm{H} 2 \mathrm{O}$ and then discarded. Subsequently, the column was eluted with $5 \mathrm{ml}$ of methanol to identify the MDA components before being put into the test tube. The collected samples were inserted into a $1 \mathrm{~cm}$ cuvette to be read uptake with a spectrophotometer at a wavelength of $532 \mathrm{~nm}$.

\subsubsection{Examination of p53 Pancreatic Expression}

a. Sampling and Pancreatic Tissue Fixation

Pancreatic sampling was performed after the mice were treated for 14 days. Cervicalis dislocasio was performed and then the mice's abdomen was dissected and the pancreatic organs were taken with great care to avoid tissue damage. The pancreatic organs were then rinsed with $0.9 \%$ of physiological $\mathrm{NaCl}$ and the liver was soaked in a PBS-Azide solution $\mathrm{pH}$ 7.4.

b. Tissue Blocking

Pieces of pancreas that were placed in pots containing formalin. The tissue were cut using microtomes. The tissue was then fixed with incubators at 370C-400C for 18-24 hours. After the fixation was complete, the tissue was fed into the aquadest solution to remove the fixation solution. The next step was the dehydration process. In the dehydration process, the tissue pieces were inserted into the alcoholic concentration of the stratified concentration. The tissue was then fed into a pure xylol alcohol solution for $2 \times 2$ hours. The next process was impregnation. The tissue was inserted in liquid paraffin for $2 \times 2$ hours. The final step was embedding. In this process, the tissue was grown in solid paraffin with a melting point of 560C-580C until the paraffin solidified.

c. Preparation of Tissue Samples for Immunohistochemistry

The immunohistochemical preparation was done at Anatomy Pathology Laboratory, Faculty of Medicine, Gadjah Mada University, Yogyakarta. Before microtomes cutting, the block was cooled by icecube or inserted in a freezer for \pm 15 minutes. The block was clipped to a microtome and then cut with a microtomic blade with a slope of \pm 300 to a paraffin block of $\pm 2-5$ microns thick. A ribbon-cut piece inserted in a water bath previously filled with warm water $\pm 500 \mathrm{C}$, then taken with a glass object and given number with a glass pencil in accordance with the registration number of the block, left for 5 minutes and then incubated. Disposable knives were used and the knives at the time of the water bath were given 50\% alcohol to lower the surface tension that helps stretch the ribbon.

d. Immunohistochemical Examination of p53 Expression

Immunohistochemistry staining was done at Parasitology Laboratory, Faculty of Medicine, UGM. The paraffin blocks were carried out with xylol for $2 \times 5$ minutes. The preparations were rehydrated using $100 \%$ ethanol, $80 \%$ ethanol, and $70 \%$ ethanol each for $2 \times 5$ min. Cold methanol was added and then thrown and soaked in peroxidase blocking solution (PBS) at room temperature for $2 \times 2$ minutes and subsequently washed with aquadest for $2 \times 2$ minutes. the preparation is then dropped with hydrogen peroxide for 10 minutes and washed with PBS for $2 \times 2$ minutes. The liver preparation was incubated in prediluted blocking serum at $25^{\circ} \mathrm{C}$ for $10 \mathrm{~min}$. Then the preparation was soaked in primary antibody at $25^{\circ} \mathrm{C}$ for 1 hour. It was then washed with PBS for $2 \times 2$ minutes, and incubated with conjugation of horseradish peroxidase at $25^{\circ} \mathrm{C}$ for 20 minutes. Then, the preparation was washed with PBS for $2 \times 2$ minutes and then it was spilled by HRP (Trek Avidin) for 10 minutes. The preparation was washed again with PBS for $3 \times 2$ min and then incubated with DAB chromogen (Diaminobenzinidine) at $25^{\circ} \mathrm{C}$ for $5 \mathrm{~min}$. The preparation was incubated again with Mayer Hematoxylin for 5 minutes, after which it was washed with running water until the color became 
purple bluish. The ethanol-dipped preparation was then dipped in xylol and covered with a glass cover. The p53 expression (brown color) was observed in cells using a light microscope with 40 times magnification.

e. Photography (Microphotography)

The portion of the preparation to be photographed was identified using a light microscope and then marked. The marked preparations were ready to be photographed. The preparations were observed using an ocular lens microscope, according to magnification and diaphragm. Once checked using an ocular lens, the camera was adjusted to gain focus. When the condition was optimum, the stock was ready to be photographed. At the same time, recording of types of preparations, magnification, antigens, and other data about films, microscopes, cameras were also performed. Each preparation was photographed 5 times per angle. For micrograph scale, a micrometer scale shoot was carried out. The expression of p53 was shown in purple brown. The color purple indicates the absence of p53 expression on the cell so it is undetectable. Percentage of expression was calculated by the number of p53 expression cells divided by the total number of observed cells multiplied by $100 \%$.

\subsection{Analysis of Data}

Blood glucose and MDA data were processed with a free version of SPSS 16. Kolmogorov Smirnov and Levene tests were used to determine the data distribution and homogeneity. If normally distributed with homogeneous variant, the data are then tested with parametric test using analysis of one-way variance (ANNOVA) to measure differences among groups. If the data is not normally distributed and not homogeneous, the non-parametric test is done using Kruskal Wallis and Mann-Whitney with 95\% confidence level. If the results are different, LSD test with 95\% confidence level is used. Mean glucose, MDA, and p53 expressions are tested on average among groups with $95 \%$ confidence level. The description of immunohistochemical results of p53 expression from each treatment group was calculated based on percentages of cells expressing p53, and then analyzed using mean difference test.

\section{RESULTS AND DISCUSSION}

\subsection{The Blood Glucose Level}

Alloxan induction causes destruction of pancreatic beta cells, decreases insulin production, and increases blood glucose levels. Blood glucose levels of test animals before and after alloxan induction and BCSO treatment are presented in Table 1. Table 1 blood glucose levels before and after alloxan induction in $\mathrm{SD}$ rats receiving $\mathrm{BCSO}$ for 9 days. The administration of $\mathrm{BCSO}$ was equivalent to the dose of thymoquinone at 6.8 and $68 \mathrm{mg} / \mathrm{kgBW}$ starting from 7 days before alloxan induction was performed. Alloxan induction was performed intraperitoneally with a dose of $125 \mathrm{mg} / \mathrm{kgBW}$ on the 7 th day. Blood glucose measurements were done on the 7th day before alloxan induction and on the 1st and 3rd days after the induction.

Table 1. Blood Glucose Levels

\begin{tabular}{lcccc}
\hline \multicolumn{1}{c}{ Experimental Group } & $\mathrm{N}$ & $\begin{array}{c}\text { Blood Glucose level before } \\
\text { induction } \\
\text { (Mean } \pm \text { SD) }(\mathrm{mg} / \mathrm{dl})\end{array}$ & $\begin{array}{c}\text { Blood Glucose level in 1st } \\
\text { day after alloxan induction } \\
\text { (Mean } \pm \text { SD) (mg/dl) }\end{array}$ & $\begin{array}{c}\text { Blood Glucose level in 3st day } \\
\text { after alloxan induction } \\
(\mathrm{Mean} \pm \mathrm{SD})(\mathrm{mg} / \mathrm{dl})\end{array}$ \\
\hline Normal & 6 & $77.88 \pm 3.38$ & $77.83 \pm 2.92$ & $79.36 \pm 2.49$ \\
Alloxan & 6 & $72.43 \pm 3.31$ & $171.13 \pm 2.92$ & $310.42 \pm 35.52$ \\
Alloxan+BCSO6.8 ml/kgBW & 6 & $76.50 \pm 2.43$ & $175.00 \pm 2.19$ & $174.30 \pm 2.06$ \\
Alloxan+BCSO68 ml/kgBW & 6 & $76.33 \pm 2.16$ & $174.23 \pm 2.37$ & $153.85 \pm 2.20$ \\
Alloxan+Simvastatin & 6 & $78.33 \pm 2.5$ & $176.59 \pm 2.57$ & $100.84 \pm 32.82$ \\
Alloxan+Vitamin C & 6 & $81.33 \pm 3.56$ & $178.50 \pm 3.27$ & $80.13 \pm 18.61$ \\
DMSO Solvent & 6 & $81.33 \pm 3.57$ & $81.33 \pm 3.56$ & $81.33 \pm 3.55$ \\
\hline
\end{tabular}

The results show that before the alloxan induction, the test animals had normal blood glucose (BG) levels and no intergroup differences. Alloxan induction has been shown to increase blood glucose levels. On the first and 3rd day after alloxan induction, blood glucose levels in experimental groups were higher than the normal or solvent groups ( $\mathrm{p}<0.05)$. BCSO administration was able to lower the BG levels, as shown by the lower BG levels of the treatment groups compared to the alloxan group $(\mathrm{p}<0.05)$, except for the BCSO6.8 group ( $\mathrm{p}>0.05)$. Data from this study show that BCSO68, simvastatin, and vitamin $\mathrm{C}$ inhibit elevated BG levels after alloxan induction. BCSO, simvastatin and vitamin $\mathrm{C}$ through the mechanism of antioxidants 
reduce the pancreatic damage caused by free radicals produced by alloxan, and thus uninterrupted insulin production and controlled blood sugar levels $[10,20]$.

\subsection{Blood Malondialdehyde Level}

Alloxan is a source of free radicals. The alloxan mechanism damages pancreatic beta cells through oxidative stress. The alloxan that enters the body releases the reactive radical compound causing oxidative stress of lipid peroxidation in the plasma membrane. Figure 1 shows that alloxan induction increases MDA levels, as shown by higher MDA levels in the alloxan group compared to the normal group ( $\mathrm{p}<0.05)$. MDA levels after alloxan induction were higher in all groups $(\mathrm{p}<0.05)$. Administration of BCSO, simvastatin and vitamin $\mathrm{C}$ decreased the MDA levels. MDA measurements were performed on day 7 before and day 9 after alloxan induction.

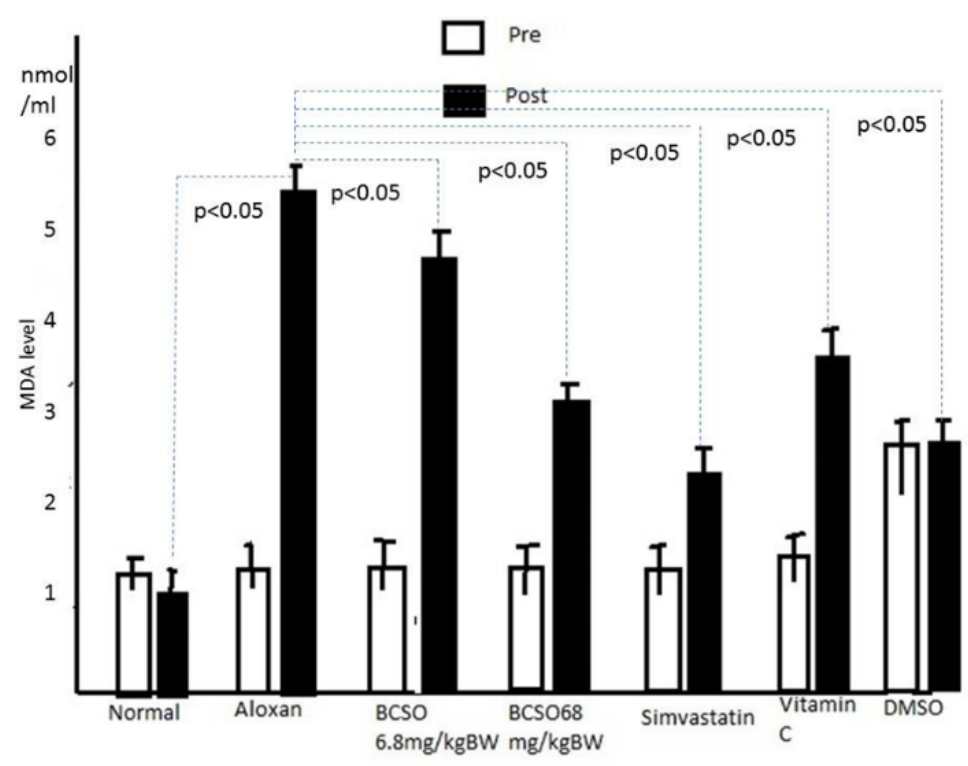

Figure 1. Malondialdehyde levels in Sprague dawley mice before and after alloxan induction in all groups

MDA levels of the simvastatin, BCSO68 and vitamin C groups were lower than those of alloxan groups $(\mathrm{p}<0.05)$. The simvastatin group had the lowest MDA levels, followed by the BCSO68 and the vitamin $\mathrm{C}$ groups $(\mathrm{p}<0.05)$. The percentage of decreased MDA levels can be seen in Figure 2 . According to Figure 2, the simvastatin group had the highest percentage of MDA decrease $(53.41 \%)$ followed by BCSO68 group (35.97\%) and the vitamin C group (35.83\%). MDA measurements were performed on Sprague dawley mice on the 3rd day after alloxan induction.

Simvastatin, vitamin C, and BCSO can serve as antioxidants and immunomodulators [23,26,27]. BCSO administration with equivalent dose of thymoquinone $68 \mathrm{mg} / \mathrm{kgBW}$ shows lower levels of MDA. These results are consistent with previous studies showing that BCSO can decrease blood glucose levels. The results of this study indicate that the pancreatic damage caused by alloxan in the BCSO groups was lower when compared to the alloxan group. Previous research has shown that thymoquinone in BCSO acts as an antioxidant by capturing the free radicals produced by alloxan and protecting pancreatic beta cells from damage caused by alloxan exposure [14]. Based on the percentages of MDA decrease in Figure 2, the simvastatin group shows MDA decrease of up to $53.41 \%$. Simvastatin has a structure like thymol because there is an $\mathrm{OH}$ group that allows it to inhibit oxidant formation. Several studies have also shown that simvastatin has antioxidant activity, protects lipid peroxidation, and increases its effect on antioxidant defenses [26.28] (Ahmed et al, 2011). The BCSO68 group shows MDA decrease of up to 35.97\%, similar to the vitamin $\mathrm{C}$ group. 


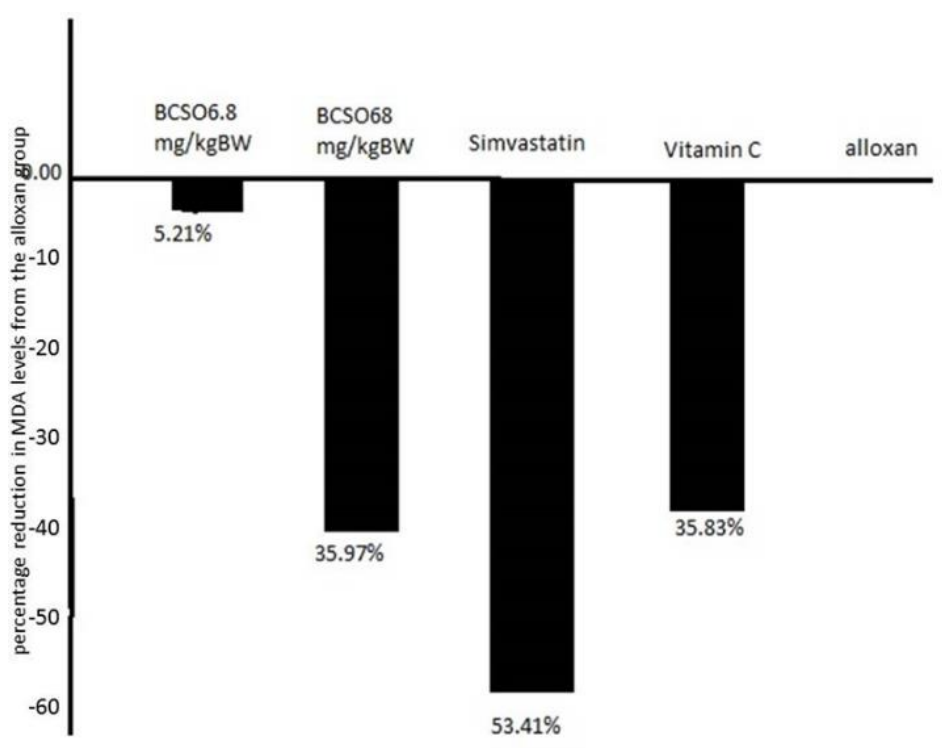

Figure 2. Percentage of MDA levels decrease after alloxan induction in the treatment groups (BCSO, simvastatin, and vitamin C)

\subsection{Pancreatic p53 Expression}

In this study, pancreatic p53 expression can be observed through immunohistochemical imaging with p53 antibody using a light microscope equipped with optilab (100x magnification). The p53 expression is indicated by the brown color of the cytoplasm and the nucleus. Microscopic pictures of p53 expression as shown in Figure 3.

The p53 expression percentages were calculated by comparing cells expressing p53 (brown) and those non-expressing p53 as listed in Table 2. From Table 2, it can be seen that alloxan induction activates the p53 gene, indicated by an increase in p53 expression after the induction. P53 gene activation was also demonstrated by a percentage increase in p53 expression in the alloxan group compared to the normal group $(\mathrm{p}<0.05)$. Based on Table 2, the increase of p53 expression in the solvent control group to normal was $59.90 \%$, which means that DMSO solvent increased p53 expression. In the alloxan group, the increase in p53 expression reached $100 \%$ compared to the normal group. However, the increase of p53 expression in the alloxan groups was lower than that in the BCSO, simvastatin, and vitamin C groups. BCSO increases the p53 expression in the alloxan-induced SD rat pancreas as shown by an increase of 263\% (BCSO6.8) and 333\% (BCSO68). The increase of p53 expression in simvastatin and vitamin C groups were lower at $150 \%$ and $184 \%$ respectively $(\mathrm{p}<0.05)$. This suggests that BCSO68 has a better effect than simvastatin and vitamin C in enhancing p53 expression.

Alloxan compounds cause p53 gene activation, followed by oxidative stress and pancreatic cell destruction $[10,16,17]$. Alloxan is a cytotoxic diabetogenic compound against pancreatic islet cells through the formation of free radicals. Oxidative stress and an increase in NF-kappaB activity in pancreatic islet cells trigger an inflammatory reaction [9]. p53 has several important roles in regulating the response to environmental stressors such as by modifying cell growth and cellular behavior in response to DNA stress and inflammation [17, 29, 30]. P53 is activated by DNA damage induced by ROS and NOS produced during inflammation. Oxidative stress due to alloxan induction causes increased ROS levels. Oxidative damage caused by free radicals has implications in various pathological conditions, namely damage to cells, tissues, and organs such as liver, kidneys, pancreas, and heart in both humans and animals $[11,12,18]$. This damage may cause death or acceleration of the onset of various degenerative diseases. Due to the potential toxicity of free radical compounds, the body has a natural defense mechanism. Endogenous antioxidant enzymes serve to neutralize and accelerate the degradation of free radical compounds to prevent damage to macromolecular components of the cell. Some of the factors that can lead to increased oxidative stress conditions include exercise, psychological stress, and inflammation $[9,19]$. 

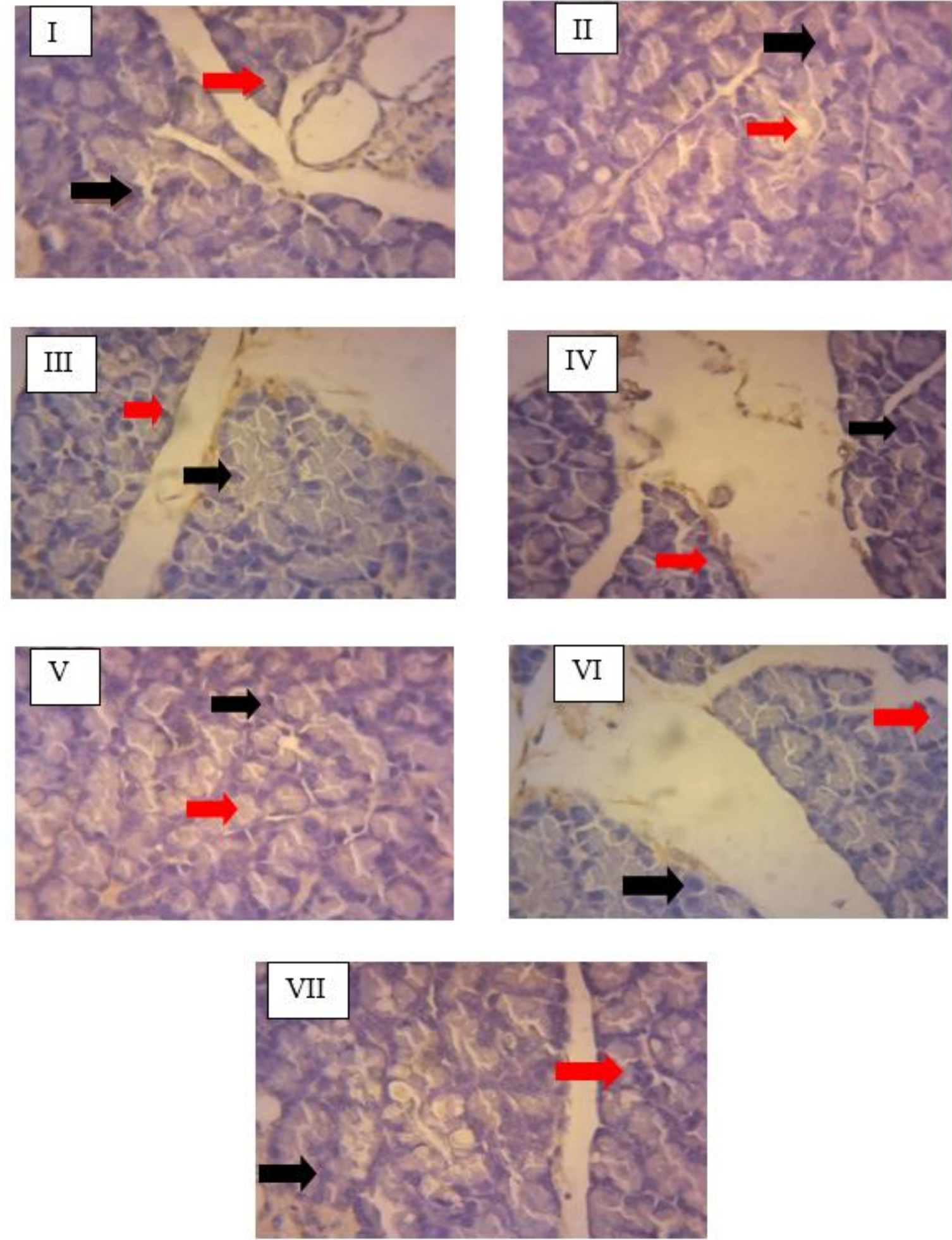

Figure 3. Microscopic photos of immunohistochemical results of p53 expression of pancreatic organs in SD rats. (IV) Alloxan + BCSO 68 mg / KgBW, (V) Alloxan + Simvastatin, (VI) Alloxan + (Alloxan + BCSO 6.8 $\mathrm{mg} / \mathrm{KgBW}$, (IV) Alloxan + Vitamin C, (VII) Solvent Control. $=$ unexpressed cells, expressed cell 
Table 2. Expression of p53 in Alloxan-Induced SD Rat Pancreas and Administration of BCSO, Simvastatin and Vitamin C

\begin{tabular}{|c|c|c|}
\hline Experimental Group & Percentages of p53 Expression & $\begin{array}{c}\text { Percentages increase of p53 expression to } \\
\text { Normal group }\end{array}$ \\
\hline Normal & $18.093 \pm 5.133$ & $0 \%$ \\
\hline Alloxan & $36.193 \pm 2.293^{*}$ & $100,038 \%$ \\
\hline Alloxan+BCSO6.8 ml $/ \mathrm{kgBW}$ & $65.671 \pm 3.617^{\wedge}$ & $262,964 \%$ \\
\hline Alloxan+BCSO68 ml/kgBW & $78.355 \pm 3.278^{\wedge}$ & $333,068 \%$ \\
\hline Alloxan+Simvastatin & $45.230 \pm 1.767^{\wedge}$ & $149,986 \%$ \\
\hline Alloxan+Vitamin C & $51.387 \pm 4.092^{\wedge}$ & $184,016 \%$ \\
\hline DMSO Solvent & $28.930 \pm 3.025$ & $59,896 \%$ \\
\hline
\end{tabular}

\section{CONCLUSION}

Alloxan induction increases blood sugar levels, Malondialdehyde levels, and p53 expression. Black seed cumin oil at a dose of $68 \mathrm{mg} / \mathrm{KgBW}$ can reduce blood glucose and MDA levels and increase pancreatic p53 expression in alloxan-induced Sprague dawley rats.

\section{ACKNOWLEDGEMENTS}

The Research Team expressed their gratitude to Center of Research and Community Service of Universitas Ahmad Dahlan, and Ministry of Research and Higher Education of Republic of Indonesia for the research funding assistance. The team also thanks the lab assistants at Gadjah Mada University testing and research center for their assistance during the research.

\section{REFERENCES}

[1] International Diabetes Federation, Diabetes Atlas 6th edition, Bruss Belg Int Diabetes Fed, 2015.

[2] Association, AD., Introduction: Standards of Medical Care in Diabetes-2018. Diabetes Care, 1;41 (Supplement 1) :S1-2, 2018.

[3] Furukawa. S., Fujita. T., Shimabukuro. M., Iwaki. M., Yamada. Y., Nakajima. Y., et al., "Increased Oxidative Stress in Obesity and Its Impact on Metabolic Syndrome", J Clin Invest, 114(12):1752-1761, 2017.

[4] Mason. RP., Jacob. RF., "Effects of Oxidative Stress, Hyperglycemia, and Hypercholesterolemia on Membrane Structural Organization and the Interactions of Omega-3 Fatty Acids", In: Membrane Organization and Dynamics. Springer; 2017. p. 31-47.

[5] Ghezzi. P., Floridi. L., Boraschi. D., Cuadrado. A., Manda. G., Levic. S., et al., "Oxidative Stress and Inflammation Induced By Environmental and Psychological Stressors: A Biomarker Perspective”, Antioxid Redox Signal, 28(9):852-872, 2018.

[6] Liu. Z., Zhu. Z., Zhao. J., Ren. W., Cai. Y., Wang. Q., et al., "Malondialdehyde: A Novel Predictive Biomarker for Post-Stroke Depression”, J Affect Disord, 220:95-101, 2017.

[7] Ogllodek EA. "The Role of PON-1, GR, IL-18, and OxLDL in Depression with and without Posttraumatic Stress Disorder", Pharmacol Rep, 69(5):837-845, 2017.

[8] Schoots. MH., Gordijn. SJ., Scherjon. SA., van. Goor. H., Hillebrands. J-L., "Oxidative Stress in Placental Pathology", Placent, 2018.

[9] Alam. MM., Meerza. D., Naseem. I., "Protective Effect of Quercetin on Hyperglycemia, Oxidative Stress and DNA Damage in Alloxan Induced Type 2 Diabetic Mice", Life Sci, 109(1):8-14, 2014.

[10] Vasu. S., McClenaghan. NH., Flatt. PR., "Molecular Mechanisms of Toxicity and Cell Damage by Chemicals in a Human Pancreatic Beta Cell Line, 1.1 B4”, Pancreas, 45(9):1320-1329, 2016.

[11] Abdul-Muneer. PM., Chandra. N., Haorah. J., "Interactions of Oxidative Stress and Neurovascular Inflammation in the Pathogenesis of Traumatic Brain Injury”, Mol Neurobio, 51(3):966-979, 2015.

[12] Durga. KD., Adhisivam. B., Vidya. G., Vishnu Bhat. B., Bobby. Z., Chand. P., "Oxidative Stress and DNA Damage in Newborns Born to Mothers with Hyperglycemia-a Prospective Cohort Study”, J Matern Fetal Neonatal Me,1-6, 2017.

[13] Agrawal. N., Hiwale. S., "Oxidative Stress in Diabetes Mellitus Patients: A Study of Malondialdehyde (Mda) and Ischemia Modified Albumin (Ima) as Indicators of Oxidative Stress", Glob J Res Anal, 7(3), 2018.

[14] Tamura. K., Minami. K., Kudo. M., Iemoto. K., Takahashi. H., Seino. S., "Liraglutide Improves Pancreatic Beta Cell Mass and Function in Alloxan-induced Diabetic Mice," PloS One, 10(5):e0126003, 2015.

[15] Ogllodek EA., "Changes in the Concentrations of Inflammatory and Oxidative Status Biomediators (MIP-1 $\alpha$, PMN elastase, MDA, and IL-12) in Depressed Patients With and Without Posttraumatic Stress Disorder", Pharmacol Rep, 2017.

[16] Dekanty. A., Barrio. L., Milan. M., "Contributions of DNA Repair, Cell Cycle Checkpoints And Cell Death to Suppressing the DNA Damage-Induced Tumorigenic Behavior of Drosophila Epithelial Cells", Oncogene, 34(8):978, 2015. 
[17] Stewart-Ornstein. J., Lahav. G., "p53 Dynamics in Response to DNA Damage Vary Across Cell Lines and are Shaped by Efficiency of DNA Repair and Activity of the Kinase ATM", Sci Signal, 10(476):eaah6671, 2017.

[18] Kumar. P., Raman. T., Swain. MM., Mishra. R., Pal. A., "Hyperglycemia-induced Oxidative-Nitrosative Stress Induces Inflammation and Neurodegeneration via Augmented Tuberous Sclerosis Complex-2 (TSC-2) activation in neuronal cells," Mol Neurobiol, 54(1):238-254, 2017.

[19] Schieber. M., Chandel. NS., "ROS Function in Redox Signaling and Oxidative Stress," Curr Biol, 24(10):R453$\mathrm{R} 462,2014$

[20] Ahmad. A., Husain. A., Mujeeb. M., Khan. SA., Najmi. AK., Siddique. NA., et al., "A Review on Therapeutic Potential of Nigella sativa: A miracle herb," Asian Pac J Trop Biomed,3(5):337-352, 2013.

[21] Lutterodt. H., Luther. M., Slavin. M., Yin. J-J., Parry. J., Gao. J-M., et al., "Fatty Acid Profile, Thymoquinone Content, Oxidative Stability, and Antioxidant Properties of Cold-Pressed Black Cumin Seed Oils," LWT-Food Sci Technol, 43(9):1409-1413, 2010.

[22] Ramadan. MF., Kroh. LW., Mörsel. J-T., "Radical Scavenging Activity of Black Cumin (Nigella sativa L.), Coriander (Coriandrum sativum L.), and Niger (Guizotia abyssinica Cass.) Crude Seed Oils and Oil Fractions," J Agric Food Chem, 51(24):6961-6969, 2003.

[23] Burits. M., Bucar. F., “Antioxidant activity of Nigella sativa Essential Oil” Phytother Res, 14(5):323-328.

[24] Hidayati. T., Habib. I., Akrom. A., "Antiimmunotoxic of Black Cumin Seed Oil (Nigella sativa Oil) in DMBA (Dimethylbenzantracene)-Induced Mice," 2015;

[25] Akrom. A., Darmawan. E., Yuhelvia. L., "Black Cumin Seed Oilas Hepatoprotector in Decreasing SGPT and SGOT Activity and Increasing P53 Gene Expression in Sprague Dawley Rats Induced by Alloxan" Int J Public Health Sci IJPHS, 4(3):159-163, 2015.

[26] Eger. GA., Ferreira. VV., Batista. CR., Bonde. H., Lima. DD. De., Wyse. AT., et al., "Antioxidant Effect of Simvastatin Throught Oxidative Imbalance Caused by Lisdexamfetamine Dimesylate" An Acad Bras Ciênc, 88(1):335-348, 2016.

[27] Thosar. SS., Bielko. SL., Wiggins. CS., Klaunig. JE., Mather. KJ., Wallace. JP., “Antioxidant Vitamin C Prevents Decline in Endothelial Function During Sitting” Med Sci Monit Int Med J Exp Clin Res, 21:1015, 2015.

[28] Zhang. G., Li. M., Xu. Y., Peng. L., Yang. C., Zhou. Y., et al., "Antioxidation Effect of Simvastatin in Aorta and Hippocampus: A Rabbit Model Fed High-Cholesterol Diet” Oxid Med Cell Longev, 2016.

[29] Cooks. T., Pateras. IS., Tarcic. O., Solomon. H., Schetter. AJ., Wilder. S., et al., "Mutant p53 Prolongs NF- $\mathrm{BB}$ Activation and Promotes Chronic Inflammation and Inflammation-associated Colorectal Cancer" Cancer Cell, 23(5):634-646, 2013.

[30] Gudkov. AV., Gurova. KV., Komarova. EA., "Inflammation and p53: a Tale of Two Stresses," Genes Cancer, 2(4):503-516, 2011 